on May 8, a "severe" one, lasting 3 seconds, took place at Plevje, in Bosnia (p. 84). From Dr. Johnston-Lavis we further learn that Vesuvius was in a state of active eruption during the end of April and the beginning of May (p. 34), but no relation is suggested even in this case, and it is quite evident that the facts do not serve to prove the connection assumed.

I do not wish to assert that in no case are synchronous earth. quakes related, for we have undoubted evidence that certain shocks have been very widesprad from a single centre (as the great Lisbon earthquake in 1755 ) ; but it is my belief that nearly every earthquake, whether large or small, is due to strictly local stratigraphical causes, quite irrespective of volcanic agency. Having made many fruit'ess attempts myself to co-ordinate different well-authenticated shocks, I have been compelled to disbelieve the theory of their general connection, and have now adduced sufficient evidence to show that the verdict pronounced by Dr. von Reheur-Paschwitz, that "we may therefore safely conclude that the disturbances noticed in Germany were really due to the volcanic action which caused the earthquakes of Tokio," is not proven, and fallacious.

4 Mecklenburgh Square, W.C.

William Wiite.

\section{The Sources of Nitrogen in Vegetation.}

THE discrepancy between the results obtained in the experiments on plants grown in free air instead of closed vessels appears to be general, as stated in NATURE (p. 3.33). Some years ayo I ventured to suggest an explanation of this, based on an observation made in the course of some investigations of atmospheric dust particles,

Sheets of paper, smeared with adhesive coatings, and shallow vessels of water, were laid on the ground in a garden near willesden. The resulting catch included far more organic than inorganic matter, the organic matter consisting chiefly of smal insects. The amount of these was surprisingly great towards the end of summer or reginning of autumn, quite sufficient, I think, to account for the varying results obtained by Sir J. B. Lawes and Prof. J. FI. Gilbert, especially for the "eccentric" behaviour of the Leguminose-" sometimes the plants died of nitrogen hunger; sometimes, after a ime of sucl hunger, they recovered and produced ahundant growth." The explanation may be confirmed or refuted by exposing an unplanted layer of sterilized sand, or otber soil, of the same area as that on which the experimental plants are growing, and comparing the gain of combined nitrogen in both cases. W. MatTIEU Writiams.

The Grange, Ncasden, August 16.

\section{Do Cats Count?}

AFTER reading all the accounts of the interesting experiments lately performed on the famous "Sally," I am persuaded the following incident may not be without a certain interest to some readers of NATURE.

About two weeks ago, the cat of a dairyman in this neigh. bourhood gave birth to three kittens. Next day, one of them was removed, during the mother's absence, and drowned. On returning from a foraging expedition, and discovering her loss, puss immediately set out in search, presumably, of the missing one. All her efforts in this direction, of course, proved fruitless ; but, evidently determined to at least make up the right number, she did so, curionsly enough, by carrying off, from its nest close by, a young hare, not more than a week old. This she is at present suckling side by side with her own kittens. In view of these facts the above question very naturally suggests itself.

Winchburgh, N.B., August 15 .

J. T. WALKER.

\section{Anapophyses.}

MY attention has been called to a statement by Prof. Cope (NATURE, July 25, p. 298), that anapophyses are "wanting from the vertebræ of anthropoid apes and man." He probably means that they are very feebly developed, which is true. I have found them, however, to exist distinctly in Troglodyles and Simia from the eleventh dorsal to the second lumbar vertebra, and in Hylobates from the tenth to the fifteenth trunk vertebra, and sometimes beginning as high up as the third dorsal vertebra.

Hurstcote, Chilworth, August I2.
The International Chemical Congress-A Correction.

A MISPRINT has occurred in the notation adopted by the Chemical Congress for phenanthrene. The Secretary of the Nomenclature Section has also informed me that a slight modification has been made on the minutes, with regard to acridine, to make the notation adopted correspond more closely to that of the other "multi-ring" compounds. The two formulæ should be-
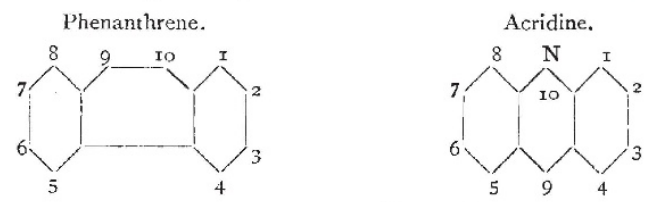

Your CorRespondentr.

\section{THE FRENCH ASSOCIATION FOR THE ADVANCEMENT OF SCIENCE.}

THE eighteenth meeting of the French Association for the Advancement of Science opened under the happiest auspices. The magnificent Exhibition on the Champ de Mars and the Esplanade des Invalides, which has attracted to Paris an exceptionally large number of foreign men of science, is in itself the most conclusive proof of French energy and the progress of French science during the last decade. It is, perhaps, as M. de Lacaze Duthiers remarked, a more effective declaration of a sincere desire for peace than the utterances of certain diplomatists. But there is no place for politics in the principles of the French Association. Foreigners of all nations have been welcomed to Paris not only with warm-hearted hospitality, but with an artistic splendour of which they may well be envious for their own countries, and to which we shall allude later.

We may mention the presence of Messrs. J. H. Gladstone, F.R.S , R. McLachlan, F.R.S., Catalan, Candèze, Istrati, Berlinerblau, Orloff, Stephanos, Van Beneden, General Wauwermans, MM. Szabo, Valdemar Schmidt, Alexeieff, Bierens de Haan, Coleman, Colley, Franchimont, William Watson, Egoroff, Joukovsky, R. de Luna, A. Macfarlane, Ragona, ThomasWilson, Benedikt, Hugo Gyldèn, Packard, Retzius, de Selys-Longchamps, Angström, Brusina, Flavitzky, Graebe, Dufour, Timiriazeff, von Goldschmidt.

The first meeting took place on Thursday, August 8, in the large hall of the Palais des Sociétés Savantes, which has just been erected by private enterprise in the quaint little rue Serpente which now affords a home to so many of the learned Societies of Paris.

The President of the Association for the year is the well-known Professor of Zoology at the Sorbonne, M. de Lacaze Duthiers, who chose as the subject of his inaugural address, "The Development of Zoological Method."

M. de Lacaze Duthiers began his address by thanking the Municipality of Paris for their invitation and for their generous subvention of $£ \mathrm{I} 200$ recently voted towards the year's expenses. He then made a touching allusion to the foundation of the Association.

"It was one day in July I87 I, that Wurtz, whose geniality and whose kindly vivacity you have not forgotten, took me, in his friendly way, by the arm, and said to me as we left the Academy of Sciences, "Come to my house to-morrow night; I want to speak to some of our colleagues of a plan which I much wish to succeed.' On the Tuesday we met at M. Wurtz's house, just a few friends, MM. Delaunay, Claude Bernard, Decaisne, and myself. One may say that this was the first meeting of the French Association.

"As the only survivor of those who were our masters and our friends, I could not forbear from speaking to you of the intimate conversation in which our Association originated. I still seem to see and hear Wurtz with his kindling enthusiasm, with an activity at times feverish, but always 